\title{
Recent trend in gastric cancer treatment in the USA
}

\author{
Kazuto Harada ${ }^{1,2}$, Hideo Baba², Jaffer A. Ajani ${ }^{1}$ \\ 1Department of Gastrointestinal Medical Oncology, University of Texas M. D. Anderson Cancer Center, Houston, TX 77030, USA. \\ ${ }^{2}$ Department of Gastroenterological Surgery, Graduate School of Medical Science, Kumamoto University, Kumamoto 860- \\ 8556, Japan.
}

Correspondence to: Dr. Jaffer A. Ajani, Department of Gastrointestinal Medical Oncology, University of Texas M. D. Anderson
Cancer Center, 1515 Holcombe Blvd, Houston, TX 77030, USA. E-mail: jajani@mdanderson.org

How to cite this article: Harada K, Baba H, Ajani JA. Recent trend in gastric cancer treatment in the USA. J Cancer Metastasis Treat 2018;4:18. http://dx.doi.org/10.20517/2394-4722.2017.74

Received: 21 Dec 2017 First Decision: 8 Jan 2018 Revised: 27 Mar 2018 Accepted: 4 Apr 2018 Published: 26 Apr 2018

Science Editor: Masayuki Watanabe Copy Editor: Jun-Yao Li Production Editor: Cai-Hong Wang

\begin{abstract}
Gastric adenocarcinoma (GAC) is estimated as the fifteenth most common cancer in the USA. Incidence rate has been gradually decreasing, but prognosis remains dismal. For patients with locally advanced GAC (stage $>$ T1B and $<$ T4B), multimodality therapies, such as surgery, chemotherapy, and radiation therapy, are needed. Perioperative chemotherapy or postoperative chemoradiation/chemotherapy is recommended. For metastatic GAC patients, combination of two cytotoxics (platinum compound and fluoropyrimidine) has become a common place in the USA, and when HER2 is positive, trastuzumab is added. When GAC progresses after the first line therapy, additional biomarkers (microsatellite instability and programmed death ligand 1) should be tested so that checkpoint inhibitors can be used. Overall, the options for advanced GAC patients are limited and more research is needed.
\end{abstract}

Keywords: Gastric adenocarcinoma, chemotherapy, chemoradiation, preoperative treatment

\section{EPIDEMIOLOGY IN THE USA}

Gastric adenocarcinoma (GAC) is estimated as the fifteenth most common cancer in the USA; 28,000 new cases are estimated in a year, which is $1.7 \%$ of all new cancer cases ${ }^{[1]}$. Incidence rate has been gradually decreasing; number of new cases per 100,000 people is 11.7 in 1975, 9.3 in 1990, 8.1 in 2000, and 6.6 in $2014^{[1]}$. In total 10,960 deaths are estimated in a year, which is $1.8 \%$ of all cancer death ${ }^{[1]}$. The 5 -year survival rate of GAC in the USA is 30.6\%; 53\% GAC are localized at diagnosis, and the 5-year survival rate of localized GAC (no lymph node involvement) and regional GAC (regional lymph node involvement) is $67.2 \%$ and $30.7 \%$, respectively ${ }^{[1]} ; 35 \%$ GAC are diagnosed as metastatic disease and have a poor outcome ${ }^{[1]}$.

\footnotetext{
(). (1)

(C) The Author(s) 2018. Open Access This article is licensed under a Creative Commons Attribution 4.0 International License (https://creativecommons.org/licenses/by/4.0/), which permits unrestricted use, sharing, adaptation, distribution and reproduction in any medium or format, for any purpose, even commercially, as long as you give appropriate credit to the original author(s) and the source, provide a link to the Creative Commons license, and indicate if changes were made.
}

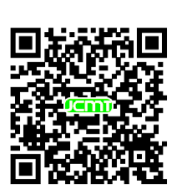


Table 1. Summary of NCCN guideline for resectable gastric adenocarcinoma

\begin{tabular}{lll}
\hline Stage & Treatment (recommendation category or comments) & Preferred regimen (recommendation category) \\
\hline cT1a & Surgery & \\
CT1b & Endoscopic resection & \\
cT2 higher & Surgery & \\
& $\begin{array}{l}\text { Perioperative chemotherapy (1) } \\
\text { (3 cycle preoperative and 3 cycle postoperative) }\end{array}$ & Fluorouracil and cisplatin (1) \\
& & Fluoropyrimidine and oxaliplatin (1A) \\
& Epirubicin, cisplatin/oxaliplatin, and fluoropyrimidine (2B) \\
& & Paclitaxel and carboplatin(1) \\
& & Fluorouracil and cisplatin (1) \\
& Postoperative chemoradiation (1) & Fluoropyrimidine and oxaliplatin (1) \\
& (for patients without preoperative treatment) & Fluoropyrimidine (1A) \\
& (before and after fluoropyrimidine-based chemoradiation) \\
& (for patients after D2 lymph node dissection) & Capecitabine and oxaliplatin (1) \\
\hline
\end{tabular}

Location of GAC had dramatically changed in the USA. Most of GAC originate from the proximal lesser curvature, cardia, and the gastroesophageal junction ${ }^{[2]}$. This location trend is considered due to environmental risk factors, such as Helicobacter pylori infection, smoking, high salt intake, and obesity.

\section{STANDARD TREATMENT FOR RESECTABLE GAC IN THE USA}

Resectable GAC patients with $\geq \mathrm{CT} 1 \mathrm{~b}$ can proceed to surgery (in the community setting) or receive preoperative therapy (in the university setting) [Table 1]. If GAC patients directly undergo surgery, postoperative chemoradiation is recommended based on the pathological stage or quality of surgery. Endoscopic resection is performed according to Japanese guideline $e^{[3]}$, but early stage (stage I) GAC is rare in the USA.

At our institution, we prefer the strategy of induction chemotherapy followed by chemoradiation and surgery ${ }^{[4,5]}$. This strategy originated at our institution (also, feasible in multi-institutional settings) and has been pursued based on excellent results recently reported ${ }^{[5]}$. Induction chemotherapy consists of 4 doses 5-fluorouracil (5-FU) and oxaliplatin administered every 2 weeks, and chemoradiotherapy consists of 45 Gy in 25 fractions with concurrent 5-FU/capecitabine with or without another cytotoxic like a platinum compound or taxane (when gastroesophageal junction is involved). After 6-8 weeks from the end of chemoradiation, a $\mathrm{D} 2$ dissection is attempted.

\section{Postoperative chemoradaiation}

SWOG 908/INT-0116, which started in 1991, is one of the most cited trials showing the survival benefit of postoperative chemoradiation for resected GAC in the USA ${ }^{[6,7]}$. In this trial, a total of 556 patients who underwent Ro resection were randomly assigned to surgery alone or surgery plus postoperative chemoradiotherapy (bolus 5-FU and leucovorin with 45 Gy radiotherapy). Compared with surgery alone group, postoperative chemoradiotherapy group showed better overall survival (OS) and relapse-free survival (RFS); the hazard ratio (HR) for OS is 1.32 [95\% confidence interval (CI) $1.10-1.60 ; P=0.0046$ ], and the HR for RFS is 1.51 (95\% CI 1.25-1.83; $P<0.001$ ). Both overall relapse and locoregional relapse were decreased in postoperative chemoradiotherapy group ${ }^{[6,7]}$. According to these results, postoperative chemoradition therapy became the standard treatment. It is appropriate only for those patients who undergo suboptimal surgery and do not received preoperative chemotherapy.

INT 0116 had some inherent drawbacks since surgical method was not part of the protocol. Thus, in the INT0116 trial, Do, D1, and D2 lymph node dissections underwent in 54\%, 36\%, and 10\% patients, respectively. Therefore, the efficacy of postoperative chemoradiation after D2 resection remains unclear. The ARTIST (Adjuvant Chemoradiation Therapy in Stomach Cancer) trial in Korea compared postoperative treatment with capecitabine plus cisplatin (XP) and XP plus radiation after curative resection with D2 lymph node dissection ${ }^{[8]}$. This trial showed that the estimated 3-year disease free survival rates were $78.2 \%$ in the chemoradiation 
group and $74.2 \%$ in XP alone group $(P=0.862)$, suggesting the addition of radiation to adjuvant XP did not significantly reduce recurrence after D2 dissection ${ }^{[8]}$. Additionally, the randomized phase III CRITICS-study assessed perioperative chemo $v$ s. postoperative chemoradiation after preoperative chemotherapy. Patients had D1+ dissection with gastrectomy in this trial. In total 788 patients were randomized into chemotherapy group ( $n=393)$ and chemoradiation group $(n=395)$, and the 5 -year survival is $41.3 \%$ for chemotherapy group and $40.9 \%$ for chemoradiation group $(P=0.99)^{[9]}$. These results suggest that postoperative chemoradiation is not useful if optimal or near-optimal surgery is performed.

Several chemotherapy regimens before and after chemoradiation were evaluated ${ }^{[10-12]}$. For instance, Korean study evaluated 5-FU plus cisplatin (FP) before and after concurrent radiotherapy with capecitabine, and this regimen was well tolerated ${ }^{[10]}$. Epirubicin, cisplatin, and 5-FU (ECF) before and after concurrent radiotherapy was assessed, and this regimen was feasible, but did not improve survival ${ }^{[1,12]}$.

\section{Perioperative chemotherapy}

Trials evaluating perioperative chemotherapy were held in Europe and its results have impacted NCCN Guideline as category 1 evidence. MAGIC trial showed an advantage in OS but control and experimental arms performed poorly ${ }^{[13]}$. The NCCN guidelines have not downgraded ECF based on toxicity issues and poor efficacy ${ }^{[13]}$. FNCLCC/FFCD trial randomly assigned 224 patients into the 2 groups: 113 to surgery plus perioperative chemotherapy ( 2 or 3 preoperative and 3 or 4 postoperative cycles of $\mathrm{FP}$ ) and 111 to surgery alone ${ }^{[14]}$. Compared with the surgery alone group, the perioperative chemotherapy group had a favorable overall survival (5-year rate, 38\% vs. 24\%; HR 0.69; 95\% CI 0.50-0.95; $P=0.02$ ) and significantly increased the Ro resection rate $(84 \%$ vs. $73 \% ; P=0.04)$, but $75 \%$ of patients in this trial had esophageal adenocarcinoma ${ }^{[14]}$. Recently, MRC-OEO5 trial compared two perioperative chemotherapy regimen, 2 cycles FP and 4 cycles ECF/ECX (epirubicin, cisplatin and capecitabine) ${ }^{[15]}$. This study showed no OS benefit for ECF/ECX compared with FP (3-year rate, 42\% vs. 39\%; HR 0.92; 95\% CI 0.79-1.08; $P=0.30$ ), suggesting that addition of epirubicin and longer duration does not provide any advantage. However, this trial predominantly included patients with lower esophageal and junctional (types I and II) adenocarcinoma, not GAC.

The FLOT4 trial, which is multicenter, randomized, and phase 3 trial, compared perioperative chemotherapy with docetaxel, oxaliplatin, and fluorouracil/leucovorin (FLOT) and ECF/ECX ${ }^{[16,17]}$. Of 716 patients, 360 patients is assigned into ECF/ECX group and 356 patients assigned into FLOT group, and FLOT improved median progression-free survival (PFS) (30 months vs. 18 months; HR 0.75; $P=0.001$ ) and median OS (50 months $v s .35$ months; HR 0.77; $P=0.012$ ) compared with ECF/ECX. Fifty percent of patients in FLOT group completed the planned postoperative treatments, while $37 \%$ of patients in ECF/ECX completed. Perioperative complications were similar across the 2 groups ${ }^{[16,17]}$. However, the FLOT regimen resulted in considerable toxicity and mortality. Some of the follow up is too early. FLOT could be recommended to only occasional fit patient for perioperative chemotherapy and we don't recommend it for regular use.

\section{Preoperative chemoradiation}

Preoperative chemoradiation for GAC is not the standard of care in the USA but it is a developing strategy. The strategy has several advantages. Firstly, radiation field is planned more accurately because primary is in place. Postoperative radiation fields were redesigned in about $35 \%$ patients in the INT-0116 trial ${ }^{[6,7]}$. Secondly, preoperative chemoradiation increases Ro resection, resulting in low local relapses rate $e^{[5]}$. Finally, preoperative chemoradiation might reduce peritoneal dissemination during surgery, however this is debatable.

A multi-institutional trial, where patients received 2 cycles of FP followed by 45 Gy of radiation concurrent with 5-FU, demonstrated that Ro resection rate was $70 \%$ and pathologic complete response (pCR) rate was $30 \%{ }^{[18]}$. Patients who achieved a good pathological response ( $<10 \%$ residual carcinoma in the primary) had a significantly longer OS than those who did not (63.9 months vs. 12.6 months; $P=0.03)^{[18]}$. In another trial, 
Table 2. Summary of NCCN guideline for metastatic gastric adenocarcinoma

\begin{tabular}{|c|c|c|}
\hline \multirow{2}{*}{$\begin{array}{l}\text { Line } \\
\text { First-line therapy }\end{array}$} & \multicolumn{2}{|c|}{ Preferred regimen (recommendation category) } \\
\hline & HER2 overexpression & $\begin{array}{l}\text { Trastsuzumab combination with fluoropyrimidine and cisplatin (1) } \\
\text { Trastsuzumab combination with other chemotherapy agents ( } 2 \mathrm{~b})\end{array}$ \\
\hline & HER2 negative & $\begin{array}{l}\text { Fluoropyrimidine and cisplatin (1) } \\
\text { Fluoropyrimidine and oxaliplatin (2A) }\end{array}$ \\
\hline & & $\begin{array}{l}\text { Paclitaxel withcisplatin or carboplatin (2A) } \\
\text { Docetaxel with cisplatin (2A) } \\
\text { Fluoropyrimidine (2A) } \\
\text { Docetaxel or paclitaxel (2A) } \\
\text { Fluorouracil and irinotecan (2A) } \\
\text { DCF modification (2A) } \\
\text { ECF or ECF modification (2B) }\end{array}$ \\
\hline \multirow[t]{3}{*}{ Second-line therapy } & & Ramucirumab and paclitaxel (1) \\
\hline & & $\begin{array}{l}\text { Paclitaxel (1) } \\
\text { Docetaxel(1) } \\
\text { Irinotecan (1) }\end{array}$ \\
\hline & & $\begin{array}{l}\text { Ramucirumab (1) } \\
\text { Fluorouracil and irinotecan (2A) } \\
\text { Irinotecan and cisplatin (2A) } \\
\text { Docetaxel and irinotecan (2B) }\end{array}$ \\
\hline
\end{tabular}

DCF: docetaxel, cisplatin, and intravenous 5-FU; ECF: epirubicin, cisplatin, and 5-FU; 5-FU: 5-fluorouracil

paclitaxel-based induction chemotherapy and chemoradiotherapy were also assessed. This trial demonstrated that pCR rate was $20 \%$, and over 36 months median survival had been estimated ${ }^{[19]}$. In these trials, laparoscopic staging and endoscopic ultrasonography were used for initial staging. Moreover, surgery was a part of sequential treatment strategy and thus was required to be high quality, such as D2 dissection. Therefore, this strategy was considered to be limited in some specialized institutions. The RTOG 9904 assessed quality, survival, and safety of this strategy with 20 institutions and demonstrated its feasibility. In this trial, the pCR and Ro resection rates were $26 \%$ and $77 \%$, respectively. A D2 dissection was performed in $50 \%$ of patients ${ }^{[20]}$.

Phase III trials to assess the value of preoperative chemoradiation in GAC, TOPGEAR trial, is currently evaluating the efficacy of adding preoperative chemoradiation to perioperative ECF (MAGIC trial regimen) ${ }^{[21]}$. The CRITICS-II trial started to assess the optimal preoperative regimen by comparing three arms; preoperative chemotherapy followed by surgery, preoperative chemotherapy and subsequent chemoradiation followed by surgery, and preoperative chemoradiation followed by surgery (NCT02931890). Results of these trials are forthcoming.

\section{STANDARD TREATMENT FOR METASTATIC GAC IN THE USA}

\section{First line therapy}

The recommended first-line therapy for patients with good performance status is a 2-drug combination of oxaliplatin plus 5-FU or capecitabine [Table 2]. Trastuzumab is added to the first line cytotoxic therapy in patients with HER2 positive GAC based on the ToGA trial ${ }^{[22]}$. Irinotecan in the first line setting did not produce OS advantage and used only for patients who are unable to tolerate platinum-based chemotherapy ${ }^{[23-25]}$. Three-drug combination of docetaxel, cisplatin, and intravenous 5-FU (DCF) or its modification is used by some but it is discouraged for two reasons: (1) it is toxic and provides marginal OS advantage and (2) it is better to avoid a taxane in the first line because one would not be able to take advantage of paclitaxel and ramucirumab in the second line. ECF is not recommended anymore in this situation ${ }^{[26]}$.

5-FU alone or in combination with various reagents used to be the key chemotherapeutic agent against metastatic GAC in the USA; FAM (5-FU, doxorubicin, and mitomycin), and FAMTX (methotrexate, 5 -FU and adriamycin) used to be standard treatment ${ }^{[27,28]}$. EAP (etoposide, adriamycin, and cisplatin) was temporarily used in the 1990s, but was discontinued due to toxicity ${ }^{[29]}$. A randomized trial showed that ECF was better than FAMTX, however remained controversial ${ }^{[30,31]}$. 
5-FU-based and cisplatin-based combinations were considered as an acceptable standard therapy according to trial in $\mathrm{Asia}^{[32]}$. Then, capecitabine, which is an oral fluoropyrimidine, and oxaliplatin, which is thirdgeneration diaminocyclohexane platinum compound, were developed. A phase III in Germany showed that the combination of fluorouracil, leucovorin, and oxaliplatin improved median PFS compared with fluorouracil, leucovorin, and cisplatin (5.8 months $v s$. 3.9 months), but not siginificant ${ }^{[33]}$. The REAL-2 trial demonstrated possible replacement of 5-FU into capecitabine or cisplatin into oxaliplatin ${ }^{[34]}$. These results have led to trend toward preference of capecitabine plus cisplatin or capecitabine plus oxaliplatin in the USA.

S-1, which is oral fluoropyrimidine preferred in Japan, was reported to be similarly effective for survival with a better toxicity compared with infusional fluorouracil in West ${ }^{[3,36]}$. However, dose of S-1 administered each time in West $\left(25 \mathrm{mg} / \mathrm{m}^{2}\right)$ is lower than that in Asia $(40-60 \mathrm{mg} / \text { body })^{[37]}$. Thus, more evidence is needed to get acceptance for $\mathrm{S}-1$ in the USA.

DCF was evaluated in a randomized study, V-325 in $2006^{[38,39]}$. It showed that median OS of DCF was significantly longer than CF (9.2 months vs. 8.6 months; $P=0.02)$, but DCF produced more toxicity ${ }^{[38,39]}$. Several modified DCF regimens demonstrated the efficacy and the safety ${ }^{[40-42]}$. Thus, the original DCF is not recommended, and modified DCF is still one of the option in specific cases.

\section{Second/third line therapy}

For second line therapy, ramucirumab (an anti-VEGFR2 monoclonal antibody) is the only molecular-targeted drug with a confirmed minimal survival benefit in a global phase 3 trial. The REGARD trial compared ramucirumab and placebo, and showed that median OS in ramucirumab group was better than that in placebo group (5.2 months $v s .3 .8$ months) ${ }^{[43]}$. The RAINBOW trial compared paclitaxel with and without ramucirumab, and showed that OS in ramucirumab plus paclitaxel was significantly longer than in placebo plus paclitaxel (median 9.6 months vs. 7.4 months) ${ }^{[44]}$. Ramucirumab plus paclitaxel is the preferred regimen in the second line setting. Docetaxel, irinotecan and paclitaxel have significantly prolong OS compared to best supportive care, but all these trials were flawed ${ }^{[45-47]}$.

Immune checkpoint blockade has received global attention in recent years ${ }^{[48-50]}$. Keynote-059 assessed efficacy and safety of pembrolizumab, programmed death-1 (PD-1) inhibitor, monotherapy showed that overall response rate (ORR) was $11.2 \%$ and median duration of response (DOR) was 8.1 months in all cohort ${ }^{[51]}$. ORR was higher in PD-1 ligand (PD-L1) positive patients than PD-L1 negative patients (15.5\% vs. 5.5\%). Checkmate 032 assessed the combination of two checkpoint inhibitors, nivolumab (PD-1 inhibitor) and ipilimumab (cytotoxic T-lymphocyte-associated protein 4 inhibitor), and showed that ORR for combination therapy in PD-L1 positive patients was $40 \%$, which was higher than nivolumab monotherapy ${ }^{[52]}$. Interestingly, among 7 patients with high microsatellite instability (MSI-H) tumors in Keynote-059, ORR was 57\% and the CR rate was $14.3 \%$. Given this result, the FDA has approved pembrolizumab for the treatment of patients with PD-L1 positive GAC who have received 2 or more lines of chemotherapy. Pembro is also approved for MSI-H tumor patients. Therefore, now we have to consider all 3 biomarkers for gastroesophageal adenocarcinoma patients (Her2, PD-L1, and MSI).

\section{PERSPECTIVE FOR TARGETED THERAPY AND IMMUNOTHERAPY}

\section{Targeted therapies against stem cells}

Cancer stem cells possess the capacity to self-renew and to cause the heterogeneous lineages of cancer cells. Several makers and pathways related to gastric cancer stemness have been identified ${ }^{[53]}$. Cancer stem cells are resistant to several chemotherapy, and thus targeting cancer stem cells is a potential therapy to overcome treatment resistance. Two stemness related pathways, Hedgehog and signal transducer and activator of transcription 3 (STAT3) pathway, were assessed in clinical trials so far. Vismodegib, which inhibit Hedgehog signals by binding smoothened (SMO), in combination with FOLFOX was assessed in phase 2, but did not benefit PFS (11.5 months vs. 9.3 months; $P=0.34)^{[54]}$. Moreover, BRIGHTER study assessed napabucasin, 
Table 3. Key trials for gastric or gastro-esophageal junction adenocarcinoma

\begin{tabular}{|c|c|c|c|c|c|c|}
\hline Study & $\begin{array}{l}\text { Enrolled } \\
\text { number }\end{array}$ & Treatment & Survival & HR $(95 \% \mathrm{Cl})$ & $P$ value & Ref. \\
\hline \multicolumn{7}{|c|}{ Pre or postoperative treatment } \\
\hline INT-0116 & $\begin{array}{l}281 \\
275\end{array}$ & $\begin{array}{l}\text { Surgery } \rightarrow 5-F U / 45 \text { Gy } \\
\text { Surgery }\end{array}$ & $\begin{array}{l}\text { Median OS: } 36 \text { months } \\
\text { Median OS: } 27 \text { months }\end{array}$ & $1.35(1.09-1.66)$ & 0.005 & {$[6]$} \\
\hline ARTIST & $\begin{array}{l}228 \\
230\end{array}$ & $\begin{array}{l}\text { Surgery } \rightarrow X P \\
\text { Surgery } \rightarrow X P / 45 \text { Gy }\end{array}$ & $\begin{array}{l}\text { 3-year DFS: } 74 \% \\
\text { 3-year DFS : 78\% }\end{array}$ & - & 0.86 & {$[8]$} \\
\hline CRITICS & $\begin{array}{l}393 \\
395\end{array}$ & $\begin{array}{l}\mathrm{ECC} \rightarrow \text { surgery } \rightarrow \mathrm{ECC} \\
\mathrm{ECC} \rightarrow \text { surgery } \rightarrow \mathrm{ECC} / 45 \mathrm{~Gy}\end{array}$ & $\begin{array}{l}\text { 5-year OS: } 41 \% \\
\text { 5-year OS: } 41 \%\end{array}$ & - & 0.99 & [9] \\
\hline $\begin{array}{l}\text { FNCLCC/ } \\
\text { FFCD }\end{array}$ & $\begin{array}{l}113 \\
111\end{array}$ & $\begin{array}{l}\text { CF } \rightarrow \text { surgery }(n=113) \\
\text { Surgery }(n=111)\end{array}$ & $\begin{array}{l}5 \text {-year rate: } 38 \% \\
5 \text {-year rate: } 24 \%\end{array}$ & $0.69(0.50-0.95)$ & 0.02 & [14] \\
\hline MAGIC & $\begin{array}{l}250 \\
253\end{array}$ & $\begin{array}{l}\mathrm{ECF} \rightarrow \text { surgery } \rightarrow \mathrm{ECF} \\
\text { Surgery }\end{array}$ & $\begin{array}{l}5 \text {-year rate: } 36 \% \\
5 \text {-year rate: } 23 \%\end{array}$ & $0.75(0.60-0.93)$ & 0.009 & [13] \\
\hline $\begin{array}{l}\text { MRC } \\
\text { OEO-5 }\end{array}$ & $\begin{array}{l}446 \\
451\end{array}$ & $\begin{array}{l}\mathrm{ECF} \rightarrow \text { surgery } \\
\mathrm{CF} \rightarrow \text { surgery }\end{array}$ & $\begin{array}{l}3 \text {-year rate: } 39 \% \\
3 \text {-year rate: } 42 \%\end{array}$ & $0.92(0.79-1.08)$ & 0.30 & [15] \\
\hline FLOT4 & $\begin{array}{l}360 \\
356\end{array}$ & $\begin{array}{l}\mathrm{ECF} \rightarrow \text { surgery } \rightarrow \text { ECF } \\
\mathrm{FLOT} \rightarrow \text { surgery } \rightarrow \text { FLOT }\end{array}$ & $\begin{array}{l}\text { Median OS: } 35 \text { months } \\
\text { Median OS: } 50 \text { months }\end{array}$ & $0.77(0.63-0.94)$ & 0.012 & [17] \\
\hline \multicolumn{7}{|c|}{ Targeted therapy } \\
\hline ToGA & $\begin{array}{l}298 \\
296\end{array}$ & $\begin{array}{l}\text { Trastuzumab }+X P \\
\text { Placebo }+X P\end{array}$ & $\begin{array}{l}\text { Median OS: } 13.8 \text { months } \\
\text { Median OS: } 11.1 \text { months }\end{array}$ & $0.74(0.60-0.91)$ & 0.0046 & {$[22]$} \\
\hline REGARD & $\begin{array}{l}238 \\
117\end{array}$ & $\begin{array}{l}\text { Ramucirumab } \\
\text { Placebo }\end{array}$ & $\begin{array}{l}\text { Median OS: } 5.2 \text { months } \\
\text { Median OS: } 3.8 \text { months }\end{array}$ & $0.78(0.60-0.99)$ & 0.047 & [43] \\
\hline RAINBOW & $\begin{array}{l}330 \\
335\end{array}$ & $\begin{array}{l}\text { Ramucirumab + paclitaxel } \\
\text { Placebo + paclitaxel }\end{array}$ & $\begin{array}{l}\text { Median OS: } 9.6 \text { months } \\
\text { Median OS: } 7.4 \text { months }\end{array}$ & $0.81(0.68-0.96)$ & 0.017 & {$[44]$} \\
\hline
\end{tabular}

OS: overall survival; DFS: disease free survival; HR: hazard ratio; Cl: confidence interval; XP: cisplatin and capecitabine; ECC: epirubicin, cisplatin and capecitabine; CF: cisplatin and 5-FU; ECF: epirubicin, cisplatin and 5-FU; FLOT: docetaxel, oxaliplatin, leucovorin, and 5-FU; 5-FU: 5 fluorouracil

STAT3 inhibitor, in combination with paclitaxe ${ }^{[55]}$. Although detail result of this trial is not available as of this date, napabucasin did not benefit $\mathrm{OS}^{[55]}$. However, these strategies might be effective for tumor with high expression of stem cell markers ${ }^{[5]}$. Further research is expected.

\section{Immunotherpy}

To enhance immune checkpoint blockade therapy, combination with several agents have been assessed. Firstly, DNA methyltransferase inhibitor have been found to upregulate interferon signaling and tumor antigen presentation ${ }^{[57]}$. Therefore, a phase $1 / 2$ study have been evaluating azacitidine in combination with pembrolizumab and epacadostat (NCT02959437). Secondly, because inducible CO-stimulator of T cells (ICOS) activate $\mathrm{T}$ cell and stimulate an anti-tumor immune response $\mathrm{e}^{[58]}$, JTX-2011, an agonist of ICOS, in combination with nivolumab is being assessed (NCT02904226).

\section{TREATMENT FOR PERITONEAL METASTATIC GAC IN THE USA}

Recommended therapy for peritoneal metastasis is systemic chemotherapy or best supportive care ${ }^{[59]}$. Hyperthermic intraperitoneal chemoperfusion (HIPEC) is a potential therapy for peritoneal metastases ${ }^{[0]}$. Our institution performed phase II study which evaluated neoadjuvant laparoscopic HIPEC (mitomycin C $30 \mathrm{mg}$ and cisplatin $200 \mathrm{mg}$ ) for GAC patients with peritoneal metastasis ${ }^{[61]}$. Seven patients $(37 \%)$ had negative peritoneal cytology after HIPEC, and the median OS from the date of diagnosis of metastatic disease was 30.2 months $^{[6]]}$. However, performing only HIPEC without systemic therapy might impair control of primary or distant disease. Therefore, further phase II trial of HIPEC (NCT02891447) is ongoing in our institution, and this result is expected.

\section{SUMMARY}

In summary, perioperative chemotherapy or preoperative chemoradiation is recommended for localized advanced GAC. Postoperative chemoradiation is option for GAC patients who undergo surgery without preoperative treatment [Table 3]. Result of trials comparing preoperative chemotherapy to chemoradiation 
is expected. Treatment strategies for metastatic GAC with HER2 negative is two-drug cytotoxic regimen; a platinum compound and a fluoropyrimidine. For GAC with HER2 positive, trastuzumab should be added. Metastatic GAC should be treated based on global trial [Table 3].

\section{DECLARATIONS}

\section{Authors' contributions}

Conception and design: Harada K, Ajani JA

Acquisition of data: Harada K

Manuscript writing: Harada K, Baba H, Ajani JA

Final approval of manuscript: Harada K, Baba H, Ajani JA

\section{Financial support and sponsorship}

This research was supported by generous grants from the Caporella, Dallas, Sultan, Park, Smith, Frazier, Oaks, Vanstekelenberg, Planjery, and Cantu families, as well as from the Schecter Private Foundation, Rivercreek Foundation, Kevin Fund, Myer Fund, Dio Fund, Milrod Fund, and The University of Texas MD Anderson Cancer Center (Houston, Texas, USA) multidisciplinary grant program. This research was also supported in part by the National Cancer Institute and Department of Defense awards CA129906. CA 127672, CA138671, and CA172741 and the DOD grants: CA150334 and CA162445 (J.A.A.), and by a grant from the Japan Society for the Promotion of Science Overseas Research Fellowships and Program for Advancing Strategic International Networks to Accelerate the Circulation of Talented Researchers (K.H.).

\section{Conflicts of interest}

The authors declare that they have no conflicts of interest.

\section{Patient consent}

Not applicable.

\section{Ethics approval}

Not applicable.

\section{Copyright}

(c) The Author(s) 2018.

\section{REFERENCES}

1. Howlader N, Noone AM, Krapcho M, Miller D, Bishop K, Kosary CL, Yu M, Ruhl J, Tatalovich Z, Mariotto A, Lewis DR, Chen HS, Feuer EJ, Cronin KA (editors). SEER Cancer Statistics Review, 1975-2014, National Cancer Institute. Based on November 2016 SEER data submission, posted to the SEER web site, April 2017. Available from: https://seer.cancer.gov/csr/1975_2014/ [Last accessed on 10 Apr 2018]

2. Blot WJ, Devesa SS, Kneller RW, Fraumeni JF Jr. Rising incidence of adenocarcinoma of the esophagus and gastric cardia. JAMA 1991;265:1287-9.

3. Japanese Gastric Cancer Association. Japanese gastric cancer treatment guidelines 2014 (ver. 4). Gastric Cancer 2017;20:1-19.

4. Elimova E, Ajani JA. Surgical resection first for localized gastric adenocarcinoma: are there adjuvant options? J Clin Oncol 2015;33:3085-91.

5. Elimova E, Slack RS, Chen HC, Planjery V, Shiozaki H, Shimodaira Y, Charalampakis N, Lin Q, Harada K, Wadhwa R, Estrella JS, Kaya DM, Sagebiel T, Lee JH, Weston B, Bhutani M, Murphy MB, Matamoros A, Minsky B, Das P, Mansfield PF, Badgwell BD, Ajani JA. Patterns of relapse in patients with localized gastric adenocarcinoma who had surgery with or without adjunctive therapy: costs and effectiveness of surveillance. Oncotarget 2017;8:81430-40.

6. Macdonald JS, Smalley SR, Benedetti J, Hundahl SA, Estes NC, Stemmermann GN, Haller DG, Ajani JA, Gunderson LL, Jessup JM, Martenson JA. Chemoradiotherapy after surgery compared with surgery alone for adenocarcinoma of the stomach or gastroesophageal junction. N Engl J Med 2001;345:725-30.

7. Smalley SR, Benedetti JK, Haller DG, Hundahl SA, Estes NC, Ajani JA, Gunderson LL, Goldman B, Martenson JA, Jessup JM, 
Stemmermann GN, Blanke CD, Macdonald JS. Updated analysis of SWOG-directed intergroup study 0116: a phase III trial of adjuvant radiochemotherapy versus observation after curative gastric cancer resection. J Clin Oncol 2012;30:2327-33.

8. Lee J, Lim DH, Kim S, Park SH, Park JO, Park YS, Lim HY, Choi MG, Sohn TS, Noh JH, Bae JM, Ahn YC, Sohn I, Jung SH, Park CK, Kim KM, Kang WK. Phase III trial comparing capecitabine plus cisplatin versus capecitabine plus cisplatin with concurrent capecitabine radiotherapy in completely resected gastric cancer with D2 lymph node dissection: the ARTIST trial. J Clin Oncol 2012;30:268-73.

9. Verheij M, Jansen EPM, Cats A, van Grieken NCT, Aaronson NK, Boot H, Lind PA, Kranenbarg EMK, Nordsmark M, Putter H, Trip AK, van Sandick JW, Sikorska K, van Tinteren H, Van De Velde CJH. A multicenter randomized phase III trial of neo-adjuvant chemotherapy followed by surgery and chemotherapy or by surgery and chemoradiotherapy in resectable gastric cancer: first results from the CRITICS study. J Clin Oncol 2016;34 Suppl 15:abstr4000.

10. Lee HS, Choi Y, Hur WJ, Kim HJ, Kwon HC, Kim SH, Kim JS, Lee JH, Jung GJ, Kim MC. Pilot study of postoperative adjuvant chemoradiation for advanced gastric cancer: adjuvant 5-FU/cisplatin and chemoradiation with capecitabine. World J Gastroenterol 2006;12:603-7.

11. Leong T, Joon DL, Willis D, Jayamoham J, Spry N, Harvey J, Di Iulio J, Milner A, Mann GB, Michael M. Adjuvant chemoradiation for gastric cancer using epirubicin, cisplatin, and 5-fluorouracil before and after three-dimensional conformal radiotherapy with concurrent infusional 5-fluorouracil: a multicenter study of the Trans-Tasman Radiation Oncology Group. Int J Radiat Oncol Biol Phys 2011;79:690-5.

12. Fuchs CS, Tepper JE, Niedzwiecki D, Hollis D, Mamon HJ, Swanson R, Haller DG, Dragovich T, Alberts SR, Bjarnason GA, Willett CG, Enzinger PC, Goldberg RM, Venook AP, Mayer RJ. Postoperative adjuvant chemoradiation for gastric or gastroesophageal junction (GEJ) adenocarcinoma using epirubicin, cisplatin, and infusional (CI) 5-FU (ECF) before and after CI 5-FU and radiotherapy (CRT) compared with bolus 5-FU/LV before and after CRT: intergroup trial CALGB 80101. J Clin Oncol 2011;29 Suppl 15:abstr4003.

13. Cunningham D, Allum WH, Stenning SP, Thompson JN, Van de Velde CJ, Nicolson M, Scarffe JH, Lofts FJ, Falk SJ, Iveson TJ, Smith DB, Langley RE, Verma M, Weeden S, Chua YJ, Participants MT. Perioperative chemotherapy versus surgery alone for resectable gastroesophageal cancer. N Engl J Med 2006;355:11-20.

14. Ychou M, Boige V, Pignon JP, Conroy T, Bouche O, Lebreton G, Ducourtieux M, Bedenne L, Fabre JM, Saint-Aubert B, Geneve J, Lasser P, Rougier P. Perioperative chemotherapy compared with surgery alone for resectable gastroesophageal adenocarcinoma: an FNCLCC and FFCD multicenter phase III trial. J Clin Oncol 2011;29:1715-21.

15. Alderson D, Langley RE, Nankivell MG, Blazeby JM, Griffin M, Crellin A, Grabsch HI, Okines AFC, Goldstein C, Falk S, Thompson J, Krysztopik R, Coxon FY, Pritchard S, Langer R, Stenning SP, Cunningham D. Neoadjuvant chemotherapy for resectable oesophageal and junctional adenocarcinoma: results from the UK Medical Research Council randomised OEO5 trial (ISRCTN 01852072). J Clin Oncol 2015;33 Suppl 15:abstr4002.

16. Al-Batran SE, Pauligk C, Homann N, Schmalenberg H, Kopp HG, Haag GM, Luley K, Folprecht G, Probst S, Thuss-Patience P, Trojan J, Koenigsmann M, Lindig U, Pohl M, Kasper S, Möhler M, Goetze T, Schuler M, Jaeger E, Hofheinz RD. LBA27_PR: Docetaxel, oxaliplatin, and fluorouracil/leucovorin (FLOT) for resectable esophagogastric cancer: updated results from multicenter, randomized phase 3 FLOT4-AIO trial (German Gastric Group at AIO). Ann Oncol 2017;28 Suppl 5:mdx440.019.

17. Al-Batran SE, Homann N, Schmalenberg H, Kopp HG, Haag GM, Luley KB, Schmiegel WH, Folprecht G, Probst S, Prasnikar N, Thuss-Patience PC, Fischbach W, Trojan J, Koenigsmann M, Pauligk C, Goetze TO, Jaeger E, Meiler J, Schuler MH, Hofheinz R. Perioperative chemotherapy with docetaxel, oxaliplatin, and fluorouracil/leucovorin (FLOT) versus epirubicin, cisplatin, and fluorouracil or capecitabine (ECF/ECX) for resectable gastric or gastroesophageal junction (GEJ) adenocarcinoma (FLOT4-AIO): a multicenter, randomized phase 3 trial. J Clin Oncol 2017;35 Suppl 15:abstr4004.

18. Ajani JA, Mansfield PF, Janjan N, Morris J, Pisters PW, Lynch PM, Feig B, Myerson R, Nivers R, Cohen DS, Gunderson LL. Multi-institutional trial of preoperative chemoradiotherapy in patients with potentially resectable gastric carcinoma. J Clin Oncol 2004;22:2774-80.

19. Ajani JA, Mansfield PF, Crane CH, Wu TT, Lunagomez S, Lynch PM, Janjan N, Feig B, Faust J, Yao JC, Nivers R, Morris J, Pisters PW. Paclitaxel-based chemoradiotherapy in localized gastric carcinoma: degree of pathologic response and not clinical parameters dictated patient outcome. J Clin Oncol 2005;23:1237-44.

20. Ajani JA, Winter K, Okawara GS, Donohue JH, Pisters PW, Crane CH, Greskovich JF, Anne PR, Bradley JD, Willett C, Rich TA. Phase II trial of preoperative chemoradiation in patients with localized gastric adenocarcinoma (RTOG 9904): quality of combined modality therapy and pathologic response. J Clin Oncol 2006;24:3953-8.

21. Leong T, Smithers BM, Michael M, Gebski V, Boussioutas A, Miller D, Simes J, Zalcberg J, Haustermans K, Lordick F, Schuhmacher C, Swallow C, Darling G, Wong R. TOPGEAR: a randomised phase III trial of perioperative ECF chemotherapy versus preoperative chemoradiation plus perioperative ECF chemotherapy for resectable gastric cancer (an international, intergroup trial of the AGITG/ TROG/EORTC/NCIC CTG). BMC Cancer 2015;15:532.

22. Bang YJ, Van Cutsem E, Feyereislova A, Chung HC, Shen L, Sawaki A, Lordick F, Ohtsu A, Omuro Y, Satoh T, Aprile G, Kulikov E, Hill J, Lehle M, Rüschoff J, Kang YK; ToGA Trial Investigators. Trastuzumab in combination with chemotherapy versus chemotherapy alone for treatment of HER2-positive advanced gastric or gastro-oesophageal junction cancer (ToGA): a phase 3, open-label, randomised controlled trial. Lancet 2010;376:687-97.

23. Guimbaud R, Louvet C, Ries P, Ychou M, Maillard E, Andre T, Gornet JM, Aparicio T, Nguyen S, Azzedine A, Etienne PL, Boucher E, Rebischung C, Hammel P, Rougier P, Bedenne L, Bouche O. Prospective, randomized, multicenter, phase III study of fluorouracil, leucovorin, and irinotecan versus epirubicin, cisplatin, and capecitabine in advanced gastric adenocarcinoma: a French intergroup 
(Federation Francophone de Cancerologie Digestive, Federation Nationale des Centres de Lutte Contre le Cancer, and Groupe Cooperateur Multidisciplinaire en Oncologie) study. J Clin Oncol 2014;32:3520-6.

24. Ajani JA, Baker J, Pisters PW, Ho L, Mansfield PF, Feig BW, Charnsangavej C. CPT-11 plus cisplatin in patients with advanced, untreated gastric or gastroesophageal junction carcinoma: results of a phase II study. Cancer 2002;94:641-6.

25. Dank M, Zaluski J, Barone C, Valvere V, Yalcin S, Peschel C, Wenczl M, Goker E, Cisar L, Wang K, Bugat R. Randomized phase III study comparing irinotecan combined with 5-fluorouracil and folinic acid to cisplatin combined with 5-fluorouracil in chemotherapy naive patients with advanced adenocarcinoma of the stomach or esophagogastric junction. Ann Oncol 2008;19:1450-7.

26. Elimova E, Ajani JA. Time-to-treatment failure as the primary end point of a first-line advanced gastric cancer randomized trial: how confused would you want us to be? J Clin Oncol 2015;33:2410.

27. Wils JA, Klein HO, Wagener DJ, Bleiberg H, Reis H, Korsten F, Conroy T, Fickers M, Leyvraz S, Buyse M. Sequential high-dose methotrexate and fluorouracil combined with doxorubicin--a step ahead in the treatment of advanced gastric cancer: a trial of the European Organization for Research and Treatment of Cancer Gastrointestinal Tract Cooperative Group. J Clin Oncol 1991;9:827-31.

28. MacDonald JS, Schein PS, Woolley PV, Smythe T, Ueno W, Hoth D, Smith F, Boiron M, Gisselbrecht C, Brunet R, Lagarde C. 5-Fluorouracil, doxorubicin, and mitomycin (FAM) combination chemotherapy for advanced gastric cancer. Ann Intern Med 1980;93:533-6.

29. Kelsen D, Atiq OT, Saltz L, Niedzwiecki D, Ginn D, Chapman D, Heelan R, Lightdale C, Vinciguerra V, Brennan M. FAMTX versus etoposide, doxorubicin, and cisplatin: a random assignment trial in gastric cancer. J Clin Oncol 1992;10:541-8.

30. Webb A, Cunningham D, Scarffe JH, Harper P, Norman A, Joffe JK, Hughes M, Mansi J, Findlay M, Hill A, Oates J, Nicolson M, Hickish T, O’Brien M, Iveson T, Watson M, Underhill C, Wardley A, Meehan M. Randomized trial comparing epirubicin, cisplatin, and fluorouracil versus fluorouracil, doxorubicin, and methotrexate in advanced esophagogastric cancer. J Clin Oncol 1997;15:261-7.

31. Ajani JA. Standard chemotherapy for gastric carcinoma: is it a myth? J Clin Oncol 2000;18:4001-3.

32. Kim NK, Park YS, Heo DS, Suh C, Kim SY, Park KC, Kang YK, Shin DB, Kim HT, Kim HJ. A phase III randomized study of 5-fluorouracil and cisplatin versus 5-fluorouracil, doxorubicin, and mitomycin $\mathrm{C}$ versus 5-fluorouracil alone in the treatment of advanced gastric cancer. Cancer 1993;71:3813-8.

33. Al-Batran SE, Hartmann JT, Probst S, Schmalenberg H, Hollerbach S, Hofheinz R, Rethwisch V, Seipelt G, Homann N, Wilhelm G, Schuch G, Stoehlmacher J, Derigs HG, Hegewisch-Becker S, Grossmann J, Pauligk C, Atmaca A, Bokemeyer C, Knuth A, Jäger E; Arbeitsgemeinschaft Internistische Onkologie. Phase III trial in metastatic gastroesophageal adenocarcinoma with fluorouracil, leucovorin plus either oxaliplatin or cisplatin: a study of the Arbeitsgemeinschaft Internistische Onkologie. J Clin Oncol 2008;26:1435-42.

34. Cunningham D, Starling N, Rao S, Iveson T, Nicolson M, Coxon F, Middleton G, Daniel F, Oates J, Norman AR; Upper Gastrointestinal Clinical Studies Group of the National Cancer Research Institute of the United Kingdom. Capecitabine and oxaliplatin for advanced esophagogastric cancer. N Engl J Med 2008;358:36-46.

35. Ajani JA, Rodriguez W, Bodoky G, Moiseyenko V, Lichinitser M, Gorbunova V, Vynnychenko I, Garin A, Lang I, Falcon S. Multicenter phase III comparison of cisplatin/S-1 with cisplatin/infusional fluorouracil in advanced gastric or gastroesophageal adenocarcinoma study: the FLAGS trial. J Clin Oncol 2010;28:1547-53.

36. Ajani JA, Buyse M, Lichinitser M, Gorbunova V, Bodoky G, Douillard JY, Cascinu S, Heinemann V, Zaucha R, Carrato A, Ferry D, Moiseyenko V. Combination of cisplatin/S-1 in the treatment of patients with advanced gastric or gastroesophageal adenocarcinoma: results of noninferiority and safety analyses compared with cisplatin/5-fluorouracil in the First-Line Advanced Gastric Cancer Study. Eur J Cancer 2013;49:3616-24.

37. Koizumi W, Narahara H, Hara T, Takagane A, Akiya T, Takagi M, Miyashita K, Nishizaki T, Kobayashi O, Takiyama W, Toh Y, Nagaie T, Takagi S, Yamamura Y, Yanaoka K, Orita H, Takeuchi M. S-1 plus cisplatin versus S-1 alone for first-line treatment of advanced gastric cancer (SPIRITS trial): a phase III trial. Lancet Oncol 2008;9:215-21.

38. Van Cutsem E, Moiseyenko VM, Tjulandin S, Majlis A, Constenla M, Boni C, Rodrigues A, Fodor M, Chao Y, Voznyi E, Risse ML, Ajani JA; V325 Study Group. Phase III study of docetaxel and cisplatin plus fluorouracil compared with cisplatin and fluorouracil as first-line therapy for advanced gastric cancer: a report of the V325 Study Group. J Clin Oncol 2006;24:4991-7.

39. Ajani JA, Fodor MB, Tjulandin SA, Moiseyenko VM, Chao Y, Cabral Filho S, Majlis A, Assadourian S, Van Cutsem E. Phase II multiinstitutional randomized trial of docetaxel plus cisplatin with or without fluorouracil in patients with untreated, advanced gastric, or gastroesophageal adenocarcinoma. J Clin Oncol 2005;23:5660-7.

40. Al-Batran SE, Hartmann JT, Hofheinz R, Homann N, Rethwisch V, Probst S, Stoehlmacher J, Clemens MR, Mahlberg R, Fritz M, Seipelt G, Sievert M, Pauligk C, Atmaca A, Jager E. Biweekly fluorouracil, leucovorin, oxaliplatin, and docetaxel (FLOT) for patients with metastatic adenocarcinoma of the stomach or esophagogastric junction: a phase II trial of the Arbeitsgemeinschaft Internistische Onkologie. Ann Oncol 2008;19:1882-7.

41. Van Cutsem E, Boni C, Tabernero J, Massuti B, Middleton G, Dane F, Reichardt P, Pimentel FL, Cohn A, Follana P, Clemens M, Zaniboni A, Moiseyenko V, Harrison M, Richards DA, Prenen H, Pernot S, Ecstein-Fraisse E, Hitier S, Rougier P. Docetaxel plus oxaliplatin with or without fluorouracil or capecitabine in metastatic or locally recurrent gastric cancer: a randomized phase II study. Ann Oncol 2015;26:149-56.

42. Shah MA, Janjigian YY, Stoller R, Shibata S, Kemeny M, Krishnamurthi S, Su YB, Ocean A, Capanu M, Mehrotra B, Ritch P, Henderson C, Kelsen DP. Randomized multicenter phase II study of modified docetaxel, cisplatin, and fluorouracil (DCF) versus DCF plus growth factor support in patients with metastatic gastric adenocarcinoma: a study of the US Gastric Cancer Consortium. J Clin Oncol 2015;33:3874-9.

43. Fuchs CS, Tomasek J, Yong CJ, Dumitru F, Passalacqua R, Goswami C, Safran H, Dos Santos LV, Aprile G, Ferry DR, Melichar B, Tehfe 
M, Topuzov E, Zalcberg JR, Chau I, Campbell W, Sivanandan C, Pikiel J, Koshiji M, Hsu Y, Liepa AM, Gao L, Schwartz JD, Tabernero J; REGARD Trial Investigators. Ramucirumab monotherapy for previously treated advanced gastric or gastro-oesophageal junction adenocarcinoma (REGARD): an international, randomised, multicentre, placebo-controlled, phase 3 trial. Lancet 2014;383:31-9.

44. Wilke H, Muro K, Van Cutsem E, Oh SC, Bodoky G, Shimada Y, Hironaka S, Sugimoto N, Lipatov O, Kim TY, Cunningham D, Rougier P, Komatsu Y, Ajani J, Emig M, Carlesi R, Ferry D, Chandrawansa K, Schwartz JD, Ohtsu A; RAINBOW Study Group. Ramucirumab plus paclitaxel versus placebo plus paclitaxel in patients with previously treated advanced gastric or gastro-oesophageal junction adenocarcinoma (RAINBOW): a double-blind, randomised phase 3 trial. Lancet Oncol 2014;15:1224-35.

45. Thuss-Patience PC, Kretzschmar A, Bichev D, Deist T, Hinke A, Breithaupt K, Dogan Y, Gebauer B, Schumacher G, Reichardt P. Survival advantage for irinotecan versus best supportive care as second-line chemotherapy in gastric cancer--a randomised phase III study of the Arbeitsgemeinschaft Internistische Onkologie (AIO). Eur J Cancer 2011;47:2306-14.

46. Kang JH, Lee SI, Lim DH, Park KW, Oh SY, Kwon HC, Hwang IG, Lee SC, Nam E, Shin DB, Lee J, Park JO, Park YS, Lim HY, Kang WK, Park SH. Salvage chemotherapy for pretreated gastric cancer: a randomized phase III trial comparing chemotherapy plus best supportive care with best supportive care alone. J Clin Oncol 2012;30:1513-8.

47. Hironaka S, Ueda S, Yasui H, Nishina T, Tsuda M, Tsumura T, Sugimoto N, Shimodaira H, Tokunaga S, Moriwaki T, Esaki T, Nagase M, Fujitani K, Yamaguchi K, Ura T, Hamamoto Y, Morita S, Okamoto I, Boku N, Hyodo I. Randomized, open-label, phase III study comparing irinotecan with paclitaxel in patients with advanced gastric cancer without severe peritoneal metastasis after failure of prior combination chemotherapy using fluoropyrimidine plus platinum: WJOG 4007 trial. J Clin Oncol 2013;31:4438-44.

48. Muro K, Chung HC, Shankaran V, Geva R, Catenacci D, Gupta S, Eder JP, Golan T, Le DT, Burtness B, McRee AJ, Lin CC, Pathiraja K, Lunceford J, Emancipator K, Juco J, Koshiji M, Bang YJ. Pembrolizumab for patients with PD-L1-positive advanced gastric cancer (KEYNOTE-012): a multicentre, open-label, phase 1b trial. Lancet Oncol 2016;17:717-26.

49. Chung HC, Arkenau HT, Wyrwicz L, Oh DY, Lee KW, Infante JR, Lee SS, Lee J, Keilholz U, Mita AC, Plummer ER, Kemeny M, Melichar B, Smith DM, Chin KM, van Heydebreck A, Cuillerot JM, Kang YK, Safran H. Avelumab (MSB0010718C; anti-PD-L1) in patients with advanced gastric or gastroesophageal junction cancer from JAVELIN solid tumor phase Ib trial: analysis of safety and clinical activity. J Clin Oncol 2016;34 Suppl 15:abstr4009.

50. Chung HC, Arkenau HT, Wyrwicz L, Oh DY, Lee KW, Infante JR, Chin KM, van Heydebreck A, Kang YK, Safran H. Safety, PDL1 expression, and clinical activity of avelumab (MSB0010718C), an anti-PD-L1 antibody, in patients with advanced gastric or gastroesophageal junction cancer. J Clin Oncol 2016;34 Suppl 4: abstr167.

51. Fuchs CS, Doi T, Jang RWJ, Muro K, Satoh T, Machado M, Sun W, Jalal SI, Shah MA, Metges JP, Garrido M, Golan T, Mandala M, Wainberg ZA, Catenacci DVT, Bang YJ, Wang J, Koshiji M, Dalal RP, Yoon HH. KEYNOTE-059 cohort 1: efficacy and safety of pembrolizumab (pembro) monotherapy in patients with previously treated advanced gastric cancer. J Clin Oncol 2017;35 Suppl 15: abstr4003.

52. Janjigian YY, Ott PA, Calvo E, Kim JW, Ascierto PA, Sharma P, Peltola KJ, Jaeger D, Evans TRJ, Braud FGD, Chau I, Tschaika M, Harbison CT, Cai W, Bendell JC, Le DT. Nivolumab \pm ipilimumab in pts with advanced (adv)/metastatic chemotherapy-refractory (CTx-R) gastric (G), esophageal (E), or gastroesophageal junction (GEJ) cancer: CheckMate 032 study. J Clin Oncol 2017;35 Suppl 15: abstr4014.

53. Bekaii-Saab T, El-Rayes B. Identifying and targeting cancer stem cells in the treatment of gastric cancer. Cancer 2017;123:1303-12.

54. Cohen DJ, Christos PJ, Kindler HL, Catenacci DVT, Bekaii-Saab TB, Tahiri S, Janjigian YY, Gibson MK, Chan E, Rajdev L, Urba S, Wade JL, Kozuch P, Love E, Vandris K, Takebe N, Hochster HS, Sparano JA. Vismodegib (V), a hedgehog (HH) pathway inhibitor, combined with FOLFOX for first-line therapy of patients (pts) with advanced gastric and gastroesophageal junction (GEJ) carcinoma: a New York Cancer Consortium led phase II randomized study. J Clin Oncol 2013;31 Suppl 15:abstr4011.

55. Sonbol MB, Bekaii-Saab T. A clinical trial protocol paper discussing the BRIGHTER study. Future Oncol 2018; doi: 10.2217/fon-20170406.

56. Yoon C, Park DJ, Schmidt B, Thomas NJ, Lee HJ, Kim TS, Janjigian YY, Cohen DJ, Yoon SS. CD44 expression denotes a subpopulation of gastric cancer cells in which Hedgehog signaling promotes chemotherapy resistance. Clin Cancer Res 2014;20:3974-88.

57. Chiappinelli KB, Strissel PL, Desrichard A, Li H, Henke C, Akman B, Hein A, Rote NS, Cope LM, Snyder A, Makarov V, Budhu S, Slamon DJ, Wolchok JD, Pardoll DM, Beckmann MW, Zahnow CA, Merghoub T, Chan TA, Baylin SB, Strick R. Inhibiting DNA methylation causes an interferon response in cancer via dsRNA including endogenous retroviruses. Cell 2015;162:974-86.

58. Dong C, Juedes AE, Temann UA, Shresta S, Allison JP, Ruddle NH, Flavell RA. ICOS co-stimulatory receptor is essential for T-cell activation and function. Nature 2001;409:97-101.

59. Ajani JA, D’Amico TA, Almhanna K, Bentrem DJ, Chao J, Das P, Denlinger CS, Fanta P, Farjah F, Fuchs CS, Gerdes H, Gibson M, Glasgow RE, Hayman JA, Hochwald S, Hofstetter WL, Ilson DH, Jaroszewski D, Johung KL, Keswani RN, Kleinberg LR, Korn WM, Leong S, Linn C, Lockhart AC, Ly QP, Mulcahy MF, Orringer MB, Perry KA, Poultsides GA, Scott WJ, Strong VE, Washington MK, Weksler B, Willett CG, Wright CD, Zelman D, McMillian N, Sundar H. Gastric Cancer, Version 3.2016, NCCN Clinical Practice Guidelines in Oncology. J Natl Compr Canc Netw 2016;14:1286-312.

60. Yonemura Y, Canbay E, Endou Y, Ishibashi H, Mizumoto A, Miura M, Li Y, Liu Y, Takeshita K, Ichinose M, Takao N, Hirano M, Sako S, Tsukiyama G. Peritoneal cancer treatment. Expert Opin Pharmacother 2014;15:623-36.

61. Badgwell B, Blum M, Das P, Estrella J, Wang X, Ho L, Fournier K, Royal R, Mansfield P, Ajani J. Phase II trial of laparoscopic hyperthermic intraperitoneal chemoperfusion for peritoneal carcinomatosis or positive peritoneal cytology in patients with gastric adenocarcinoma. Ann Surg Oncol 2017;24:3338-44. 